\title{
The Relationships Between the Financial Literacy Levels of Individuals and Their Financial Innovation Utilization Habits: The Case of Kayseri Province*
}

\author{
Derviş Boztosun \\ Erciyes University, Kayseri, Turkey
}

\begin{abstract}
Organizations and researchers use different names and definitions for financial literacy. Although the concepts of "financial training", "financial awareness", and "financial sufficiency" are used in the literature, the concept of "financial literacy" has been recognized in Turkey. Financial literacy can be defined as the ability to comprehend financial concepts and issues so as to take proper decisions against changing financial conditions and to manage one's own financial status through financial planning. Financial innovation is defined in the broad sense as the products or processes developed to benefit from the profit opportunities which arise from incomplete financial markets or inefficient financial intermediation. Increasing savings through deposits and personal pensions in recent years and increasing debts through loans and credit cards have revealed a very high level of financial operations and activities in Turkey. The utilization of new financial instruments is also expected to increase with these intense financial activities. Parallel to such increases, individuals with high financial literacy levels are expected to have a higher knowledge level about new financial instruments and innovations and they are also expected to have a greater tendency to use such instruments. In accordance with these expectations, significant relationships were observed in this survey study between the financial literacy level of individuals living in Kayseri province and their utilization habits of many of financial innovations.
\end{abstract}

Keywords: financial literacy, financial innovation, Kayseri

\section{Introduction}

The rapid and comprehensive changes which have been experienced in the financial world recently and are expected to continue in the future involve quite diversified financial tools, processes, and implementations. All these issues have carried the significance of financial literacy to higher levels.

As compared to the past, individuals today are more frequently faced with financial events in their daily routines and forced to make a number of financial decisions. For instance, financial tools and processes which were not commonly encountered in the past but are frequently encountered today such as credit cards, personal and mortgage loans, personal pensions, insurance policies, bonds, and equities; require a degree of knowledge

\footnotetext{
* This study was supported by Erciyes University Scientific Research Projects Coordination Department. Project Number: SHD-2017-7231.

Derviş Boztosun, associate professor, Colleges of Applied Sciences, Erciyes University, Kayseri, Turkey.

Correspondence concerning this paper should be addressed to Derviş Boztosun, Erciyes Üniversitesi, Uygulamalı Bilimler Yüksekokulu, Kayseri 38039, Turkey.
} 
and effort to allow individuals to make the right choices. High financial literacy levels allow individuals to be more conscious about the subject of financial instruments and services; as well as which ones are more to their advantage or best suited to their interests; and to ultimately ease their decisions on financial issues.

The financial decisions to be made by individuals in society influence not only their own futures, but also the economic future of the country. Therefore, several researchers, academics, as well as national and international organizations have recently focused their studies on the concept of financial literacy. The majority of these studies indicated the reason for the low financial literacy level of individuals as the lack of education and training about financial issues throughout their educational lives (Crain, 2013, p. 2; DeLaune, J. S. Rakow, \& K. C. Rakow, 2010, p. 103).

The problems created by individuals making the wrong decisions in selecting financial tools and processes because of low financial literacy levels influence not only developing countries, but also developed countries. This situation has therefore led both developed and developing countries to develop various strategies to improve the financial literacy levels of individuals.

In this survey study, the relationships between the financial literacy levels of individuals living in Kayseri province and their financial innovation utilization levels were examined. Such levels were also compared based on the demographic characteristics of the participants. Potential findings on financial innovation utilization levels are expected to provide guidance for future financial training programs to be organized by public authorities and non-governmental organizations to improve the financial literacy levels of individuals.

\section{Financial Literacy}

Several definitions of financial literacy have been given in the literature by researchers. The concept in a broad sense was handled by some researchers as to cover not only economy-related issues, but also the effects of economic conditions on the decisions and attitudes of individuals. In the strict sense, on the other hand, the concept focuses on savings, budgeting, insurance, and investment-like basic monetary management issues (Worthington, 2006, p. 59).

According to the definition of Bodie (2006) which was made by taking the issues about which knowledge is required into consideration, financial literacy was expressed as the ability to develop attitudes in the light of information about borrowing/lending, budgeting, saving, investment, diversification, insurance, and the balancing of income and expenses.

Lusardi (2008) separated financial literacy into two levels as basic and advanced. According to this classification, basic financial literacy covers simple concepts like the operation of interest rates, impacts of inflation and risk distribution. Advanced financial literacy includes advanced concepts like the relationships between risk and return, the operation of bonds, equities, and investment funds.

According to Remund (2010), the financial literacy level of an individual was expressed as his/her level of comprehension of basic financial concepts, the ability to take proper decisions in the face of changing economic conditions, and having sufficient trust and ability to manage his/her own financial status through financial planning.

In another study, financial literacy is defined as the financial awareness, knowledge, experience, attitude, and behaviors required to make proper financial decisions and to acheive individual financial welfare (Atkinson $\&$ Messy, 2012, p. 14). This definition is also used by the INFE (International Network on Financial Education) which was founded within the body of the OECD (Organization for Economic Cooperation and Development) 
and focuses mostly on financial literacy training.

Goel and Khanna (2013) defined financial literacy as the ability of individuals to make conscious assessments in monetary management and to make efficient decisions accordingly.

As can be inferred from these definitions, the concept of financial literacy has not yet been fully defined, but only founded on certain bases. It is quite possible that it will be extended to include new features based on developments in the financial world.

\section{Financial Innovation}

Financial innovations allow users to perform financial operations faster and with lower costs, and also offer alternative products and tools for payments. Besides these advantages, such innovations may have some negative attributes with regard to the safety and risks of operations. However, despite these negative aspects, innovations have always been seen as a means to gain a competitive advantage in markets (Wakelin, 1998, pp. 829-835).

Several definitions of financial innovation have been given in the literature by various researchers and distinctions have also been made based on various criteria.

Van Horne (1985) defined the concept of financial innovation in a broad sense as the products or processes developed to benefit from profit opportunities which arise from incomplete financial markets or inefficient financial intermediation.

Product-based financial innovations are developed as a result of general variations in economic conditions. On the other hand, process-based financial innovations are developed as technology-induced alternative payment tools such as Automatic Teller Machines (ATMs), the Electronic Fund Transfer (EFT) system, financial operations made with personal computers, Point of Sale (POS) terminals etc. (Van Horne, 1985, p. 625).

Financial innovations were separated into two groups by Podolski (1986) based on the effects of legal regulations on monetary policies as innovations with a direct effect on a monetary sum and innovations with an indirect effect on a monetary sum.

Llewellyn (1992) stated that the concept of financial innovation should be considered as a reflection and consequence of structural changes which have taken place in financial systems over the years from the 1980s to the present day. In the same study, financial innovations were classified under four main headings as attack innovations, defensive innovations, protective innovations, and change-response innovations.

Frame and White (2002) indicated that financial innovations could be defined as new services, new products, new processes, or organizational innovations developed by the companies providing financial services.

According to the definition made by Tufano (2002), financial innovation is the creation of widespread new financial instruments and financial technologies to be used in markets.

\section{Literature}

When the relevant literature was reviewed, it was observed that different organizations, institutes, and academics have conducted research to determine the financial literacy levels of individuals or different groups, their attitudes toward financial innovations and to identify the factors influencing these two issues. There are also some studies which examine the relationships between financial literacy levels and attitudes toward financial innovations. 
Minehan (2006) and Fluch (2007) carried out a study about Central Banks and financial literacy and indicated that individuals with high financial literacy levels were more competent in making decisions about consumption, saving, and investment and such competence thus contributed to financial stability, market efficiency, and economic development.

Lusardi and Tufano (2009) indicated in a study that individuals with high financial literacy levels were able to better identify their solvency, exhibited more appropriate attitudes while making debt decisions, and were able to avoid fees and operational costs or high-cost debt tools.

Hastings, Madrian, and Skimmyhom (2012) carried out a study about financial literacy, financial training, and financial outcomes of these concepts and indicated a relationship between the financial literacy levels of individuals and their stock market operations and investment decisions. Researchers also indicated that individuals with low financial literacy levels more commonly exhibited negative behaviors about low-cost debts, borrowing in accordance with solvency, proper credit selection, and timely payment of debts.

Hilgertand Hogarth (2013) carried out a study to identify the relationships between the financial literacy levels of individuals and their financial attitudes and indicated significant correlations between the financial literacy levels of individuals and their financial decisions and financial attitudes.

Fettahoğlu (2015) in a household study carried out in Kocaeli province asked the participants about some financial tools they use and identified the most commonly used financial tools as credit cards, ATM, transfer/EFT, and the least common financial tools as futures, bonds/bills, and repo tools. The researcher concluded that participants generally abstained from financial tools requiring certain background information.

\section{Research Methodology}

\section{Research Objectives, Model, and Hypotheses}

The primary objective of this study was to inquire into the relationships between the financial literacy levels of individuals living in Kayseri province and their financial innovation utilization habits. Initially, the financial literacy levels of the individuals were determined based on the number of correct answers they provided to eight questions in the second section of the questionnaire. The individuals in the research sample were divided into two groups as, in Aksoylu, Boztosun, Altinişik, and Baraz (2017). The individuals with four and less correct answers were placed in the "Unsuccessful" group and those with five and more correct answers were placed in the "Successful" group. Information about the study groups is provided in Table 1.

Table 1

Financial Literacy Success Status

\begin{tabular}{lll}
\hline & Frequency & $\%$ \\
\hline Unsuccessful & 75 & 18.8 \\
Successful & 325 & 81.2 \\
Total & 400 & 100 \\
\hline
\end{tabular}

In keeping with the objectives of the study, we tried to identify the financial innovation utilization habits of individuals in the second section. To do this, the studies of Fettahoğlu (2015), Çıkrıkçı and Karakaya (2004), and Bhushan (2014) were used and individuals were asked whether or not they used financial innovations in the third section of the questionnaire. In those studies, the following products and processes were indicated as financial innovation: 
- $\operatorname{ATM}$ (Automatic Teller Machine);

- Internet Banking (banking operations through bank web-sites);

- Telephone Banking (banking operations through customer services hotlines);

- Mobile Banking (banking operations through smart phones, tablet PC etc.);

- EFT (Electronic Fund Transfer);

- Credit Card;

- PPS (Personal Pension System);

- Mortgage Loan;

- Consumer Loans (loans apart from mortgage loans);

- Private Insurance Policies (Health, earthquake, fire, car insurance etc.);

- Automatic Payment Order;

- Virtual POS (shopping through the internet by providing credit card information);

- Investment Trust (investment instruments composed of financial products like stocks, bonds etc.).

Distribution of the utilization habits of individuals for the above-mentioned financial innovations based on their financial literacy success status is provided in Table 2.

Table 2

Financial Innovation Utilization Habits Based on Financial Literacy Success Status

\begin{tabular}{llll}
\hline \multirow{2}{*}{ Number of financial innovations used } & \multicolumn{2}{c}{ Success status } & Total \\
\cline { 2 - 4 } & Unsuccessful & Successful & 4 \\
\hline 0 & 0 & 4 & 19 \\
1 & 2 & 17 & 26 \\
2 & 2 & 24 & 27 \\
3 & 5 & 22 & 37 \\
4 & 4 & 33 & 64 \\
5 & 9 & 55 & 58 \\
6 & 10 & 48 & 45 \\
7 & 12 & 33 & 21 \\
8 & 2 & 19 & 24 \\
9 & 4 & 20 & 23 \\
10 & 5 & 18 & 25 \\
11 & 9 & 16 & 20 \\
12 & 4 & 16 & 7 \\
13 & 7 & 0 & 400 \\
\hline
\end{tabular}

After gathering the relevant information, the following hypotheses were tested for each financial innovation to assess the financial innovation utilization habits of individuals in the "Successful" and "Unsuccessful" groups.

$\mathrm{H}_{0}$ : The financial innovation utilization habits of individuals do not depend on their financial literacy success status.

$\mathrm{H}_{1}$ : The financial innovation utilization habits of individuals depend on their financial literacy success status.

The Pearson Chi-Square test was used to test the above hypotheses for each financial innovation. This test investigates the significance of the relationship between two factors in tables used for qualitative factors. The $\chi^{2}$ 
value is calculated as follows (Yıldı \& Bircan, 2006, p. 244);

$$
\chi^{2}=\frac{\left(g_{i j}-b_{i j}\right)^{2}}{b_{i j}}
$$

where

$\mathrm{g}_{\mathrm{ij}}$ : observed value at $\mathrm{i}^{\text {th }}$ row and $\mathrm{j}^{\text {th }}$ column,

$b_{i j}$ : expected value at $i^{\text {th }}$ row and $j^{\text {th }}$ column.

The expected value is calculated by using the following equation:

$$
b_{i j}=\frac{r_{i} \times c_{j}}{T}
$$

where

$r_{i}$ : sum of $i^{\text {th }}$ row,

$c_{\mathrm{j}}$ : sum of $\mathrm{k}^{\text {th }}$ row,

$\mathrm{T}$ : general sum.

SPSS 22.0 software was used for Chi-Square analysis. The resulting data are provided in the results section.

\section{Universe and Sample}

Since the research was conducted in Kayseri province, individuals aged 15+ living in Kayseri constituted the research universe. According to the Turkish Statistics Institute, there are 1,018,084 individuals over 15 years of age in Kayseri ${ }^{1}$. Since the time and budget restricted reaching the entire universe, a sample was created through statistical methods so as to qualitatively and quantitatively represent the research universe.

The following equation was used to determine the size of the sample created through a simple randomized sampling method:

$$
n=\frac{N \times z_{\alpha / 2}^{2} \times \hat{p} \times \widehat{q}}{\left((N-1) \times d^{2}\right)+\left(z_{\alpha / 2}^{2} \times \hat{p} \times \hat{q}\right)}
$$

where

$\mathrm{N}$ : universe size,

$\alpha$ : significance level,

$\mathrm{z}_{\alpha / 2}: \mathrm{z}$ value for desired probability level,

p: sample ratio,

q: 1-q value,

$\mathrm{d}$ : deviation between sample value to be estimated and calculated sample value.

"The simple randomized sampling method" used to create the present sample has a representative power for universe characteristics and every single individual in the universe has an equal chance of eligibility" (Wimmer \& Dominick, 2000, pp. 85-87).

\section{Data Gathering and Analysis Methods}

The research universe was constituted by individuals living in Kayseri province. Within this universe, a sample was created by using statistical methods so as to represent the universe qualitatively and quantitatively.

\footnotetext{
${ }^{1}$ Data were obtained from the Central Dissemination System of TUIK on 25/11/2017.
} 
A questionnaire was applied to the sample through face-to-face meetings.

The questionnaire form used in this survey study was composed of three sections. The first section was composed of questions inquiring into the demographic characteristics of the participants. Questions in this section inquired into the gender, age, education, income, and occupation of the participants. In the second section, participants were asked questions complying with the "simple division", "time value of Money", "paid interest", "simple interest", "compound interest", "risk and return", "inflation", and "financial diversification" headings universally used by the OECD to determine financial literacy levels of individuals. The studies of Cihangir and Engin (2015), Alkaya and Yağlı (2015), and OECD scale-preparation guidelines were used to form a scale in this study. In the last section, a scale was created by using the studies of Fettahoğlu (2015), Çıkrıç̧ı and Karakaya (2004), and Bhushan (2014).

Questionnaires were applied to participants through face-to-face meetings and data were gathered to fulfill the objectives of the study. Invalid questionnaires were excluded and statistical analyses were performed on the 400 valid questionnaires.

In brief, a questionnaire was applied to participants to identify the relationships between the financial literacy levels of individuals living in Kayseri province and their financial innovation utilization habits. The outcomes of the study revealed province-specific information about such relationships.

\section{Results}

This section includes statistical data resulting from the responses of participants to questions about their demographic characteristics in the first section of the questionnaire, to questions asked to measure their basic financial literacy levels in the second section of the questionnaire, and to questions asked to determine whether or not they use financial innovations.

Questions were asked about the demographic characteristics of the participants (genders, occupations, age, educational and income levels) in the first section of the questionnaire and the resulting data are provided in Table 3.

As can be seen from Table 3, a total of 400 individuals were included in this research (200 females and 200 males) to create the research sample.

Considering the participant responses to the question inquiring about their occupations, participants were placed under eight different occupational groups. With regard to the occupations of participants, private sector employees (blue-collar) were prominent $(25.7 \%)$. The occupational groups with the least participants were retired $(3.5 \%)$ and home-makers $(3.5 \%)$.

With regard to the age groups of participants, the $\geq 35$ years old age group was the largest $(24.0 \%)$ and it was followed by the 31-35 years old group (23.20\%). The age group with the least participants was the 15-20 years old age group (11.0\%).

Considering the educational levels of participants, it was observed that the majority of participants had an undergraduate degree (37.3\%) and this was followed by high-school graduates $(28.6 \%)$. The ratio of graduate level education was quite low (2.0\%).

With regard to the monthly income levels of the participants, the largest group (26.0\%) had a monthly income of between 1,001 $₹-2,000$ because of minimum wage regulations. This group was followed by the $\leq 1,000 €(25.0 \%)$ income group because this group was mostly composed of housewives and students. The group with the lowest number of individuals was the $\geq 4,000$ ₹ (7.5\%) income group. 
Table 3

Demographic Characteristics

\begin{tabular}{|c|c|c|c|c|c|}
\hline Gender & Frequency & $\%$ & Age groups & Frequency & $\%$ \\
\hline Female & 200 & 50 & $15-20$ & 44 & 11.0 \\
\hline Male & 200 & 50 & $21-25$ & 83 & 20.8 \\
\hline Total & 400 & 100 & $26-30$ & 84 & 21.0 \\
\hline Occupation & Frequency & $\%$ & $31-35$ & 93 & 23.2 \\
\hline Unemployed & 21 & 5.3 & 35 and over & 96 & 24.0 \\
\hline Private sector (blue-collar) & 103 & 25.7 & Total & 400 & 100 \\
\hline Private sector (white-collar) & 59 & 14.7 & Educational level & Frequency & $\%$ \\
\hline Public sector (blue-collar) & 31 & 7.8 & Primary school & 20 & 5.0 \\
\hline Public sector (white-collar) & 48 & 12.0 & Secondary school & 49 & 12.3 \\
\hline Self-employed & 50 & 12.5 & High school & 115 & 28.6 \\
\hline Retired & 14 & 3.5 & Associate degree & 59 & 14.8 \\
\hline Housewife & 14 & 3.5 & Undergraduate & 149 & 37.3 \\
\hline Student & 60 & 15.0 & Graduate & 8 & 2.0 \\
\hline \multirow[t]{8}{*}{ Total } & 400 & 100 & Total & 400 & 100 \\
\hline & & & Income level ( $も /$ month) & Frequency & $\%$ \\
\hline & & & 1,000 and below & 100 & 25.0 \\
\hline & & & $1,001 \quad-2,000$ & 104 & 26.0 \\
\hline & & & $2,001 \quad-3,000$ & 87 & 21.8 \\
\hline & & & $3,001 \quad-4,000$ & 79 & 19.7 \\
\hline & & & 4,001 and over & 30 & 7.5 \\
\hline & & & Total & 400 & 100 \\
\hline
\end{tabular}

The utilization ratios of relevantfinancial innovations were determined based on the demographical characteristics of the participants.

The financial innovation utilization ratios of the genders are provided in Table 4.

Table 4

Financial Innovation Utilization Ratios of the Genders

\begin{tabular}{|c|c|c|c|c|c|}
\hline & & \multicolumn{4}{|c|}{ Gender } \\
\hline & & \multicolumn{2}{|c|}{ Female } & \multicolumn{2}{|c|}{ Male } \\
\hline & & $\mathrm{F}$ & $\%$ & $\mathrm{~F}$ & $\%$ \\
\hline \multirow{2}{*}{ ATM } & Yes & 193 & 96.5 & 194 & 97.0 \\
\hline & No & 7 & 3.5 & 6 & 3.0 \\
\hline \multirow{2}{*}{ Internet bank. } & Yes & 129 & 64.5 & 144 & 72.0 \\
\hline & No & 71 & 35.5 & 56 & 28.0 \\
\hline \multirow{2}{*}{ Telephone bank } & Yes & 138 & 69.0 & 164 & 82.0 \\
\hline & No & 62 & 31.0 & 36 & 18.0 \\
\hline \multirow{2}{*}{ Mobile bank } & Yes & 123 & 61.5 & 148 & 74.0 \\
\hline & No & 77 & 38.5 & 52 & 26.0 \\
\hline \multirow{2}{*}{ EFT } & Yes & 103 & 51.5 & 133 & 66.5 \\
\hline & No & 97 & 48.5 & 67 & 33.5 \\
\hline \multirow{2}{*}{ Credit card } & Yes & 161 & 80.5 & 149 & 74.5 \\
\hline & No & 39 & 19.5 & 51 & 25.5 \\
\hline \multirow{2}{*}{ PPS } & Yes & 53 & 26.5 & 47 & 23.5 \\
\hline & No & 147 & 73.5 & 153 & 76.5 \\
\hline
\end{tabular}


(Table 4 continued)

\begin{tabular}{|c|c|c|c|c|c|}
\hline & & \multicolumn{4}{|c|}{ Gender } \\
\hline & & \multicolumn{2}{|c|}{ Female } & \multicolumn{2}{|c|}{ Male } \\
\hline & & $\mathrm{F}$ & $\%$ & $\mathrm{~F}$ & $\%$ \\
\hline \multirow{2}{*}{ Mortgage loan } & Yes & 32 & 16.0 & 35 & 17.5 \\
\hline & No & 168 & 84.0 & 165 & 82.5 \\
\hline \multirow{2}{*}{ Consumer loan } & Yes & 39 & 19.5 & 61 & 30.5 \\
\hline & No & 161 & 80.5 & 139 & 69.5 \\
\hline \multirow{2}{*}{ Private insurance } & Yes & 63 & 31.5 & 71 & 35.5 \\
\hline & No & 137 & 68.5 & 129 & 64.5 \\
\hline \multirow{2}{*}{ Auto. pay. order } & Yes & 102 & 51.0 & 106 & 53.0 \\
\hline & No & 98 & 49.0 & 94 & 47.0 \\
\hline \multirow{2}{*}{ VPOS } & Yes & 156 & 78.0 & 116 & 58.0 \\
\hline & No & 44 & 22.0 & 84 & 42.0 \\
\hline \multirow{2}{*}{ Investment trust } & Yes & 12 & 6.0 & 25 & 12.5 \\
\hline & No & 188 & 94.0 & 175 & 87.5 \\
\hline
\end{tabular}

The ATM was the most frequently used financial innovation by female $(96.5 \%)$ and male (97.0\%) participants. Investment trust was the least frequently used financial innovation by female $(6.0 \%)$ and male (12.5\%) participants.

The financial innovation utilization ratios of the age groups are provided in Table 5.

Table 5

Financial Innovation Utilization Ratios of the Age Groups

\begin{tabular}{|c|c|c|c|c|c|c|c|c|c|c|c|}
\hline & & \multicolumn{10}{|c|}{ Age group } \\
\hline & & \multicolumn{2}{|c|}{$15-20$} & \multicolumn{2}{|c|}{$21-25$} & \multicolumn{2}{|c|}{$26-30$} & \multicolumn{2}{|c|}{$31-35$} & \multicolumn{2}{|c|}{$35+$} \\
\hline & & $\mathrm{F}$ & $\%$ & $\mathrm{~F}$ & $\%$ & $\mathrm{~F}$ & $\%$ & $\mathrm{~F}$ & $\%$ & $\mathrm{~F}$ & $\%$ \\
\hline \multirow{2}{*}{ ATM } & Yes & 40 & 90.9 & 82 & 98.8 & 84 & 100.0 & 93 & 100.0 & 88 & 91.7 \\
\hline & No & 4 & 9.1 & 1 & 1.2 & 0 & 0.0 & 0 & 0.0 & 8 & 8.3 \\
\hline \multirow{2}{*}{ Internet bank } & Yes & 20 & 45.5 & 75 & 90.4 & 64 & 76.2 & 69 & 74.2 & 45 & 46.9 \\
\hline & No & 24 & 54.5 & 8 & 9.6 & 20 & 23.8 & 24 & 25.8 & 51 & 53.1 \\
\hline \multirow{2}{*}{ Telephone bank } & Yes & 22 & 50.0 & 75 & 90.4 & 69 & 82.1 & 77 & 82.8 & 59 & 61.5 \\
\hline & No & 22 & 50.0 & 8 & 9.6 & 15 & 17.9 & 16 & 17.2 & 37 & 38.5 \\
\hline \multirow{2}{*}{ Mobile bank } & Yes & 20 & 45.5 & 70 & 84.3 & 67 & 79.8 & 71 & 76.3 & 43 & 44.8 \\
\hline & No & 24 & 54.5 & 13 & 15.7 & 17 & 20.2 & 22 & 23.7 & 53 & 55.2 \\
\hline \multirow{2}{*}{ EFT } & Yes & 15 & 34.1 & 52 & 62.7 & 62 & 73.8 & 62 & 66.7 & 45 & 46.9 \\
\hline & No & 29 & 65.9 & 31 & 37.3 & 22 & 26.2 & 31 & 33.3 & 51 & 53.1 \\
\hline \multirow{2}{*}{ Credit card } & Yes & 22 & 50.0 & 61 & 73.5 & 75 & 89.3 & 81 & 87.1 & 71 & 74.0 \\
\hline & No & 22 & 50.0 & 22 & 26.5 & 9 & 10.7 & 12 & 12.9 & 25 & 26.0 \\
\hline \multirow{2}{*}{ PPS } & Yes & 1 & 2.3 & 14 & 16.9 & 33 & 39.3 & 29 & 31.2 & 23 & 24.0 \\
\hline & No & 43 & 97.7 & 69 & 83.1 & 51 & 60.7 & 64 & 68.8 & 73 & 76.0 \\
\hline \multirow{2}{*}{ Mortgage loan } & Yes & 1 & 2.3 & 7 & 8.4 & 12 & 14.3 & 26 & 28.0 & 21 & 21.9 \\
\hline & No & 43 & 97.7 & 76 & 91.6 & 72 & 85.7 & 67 & 72.0 & 75 & 78.1 \\
\hline \multirow{2}{*}{ Consumer loan } & Yes & 3 & 6.8 & 13 & 15.7 & 25 & 29.8 & 29 & 31.2 & 30 & 31.3 \\
\hline & No & 41 & 93.2 & 70 & 84.3 & 59 & 70.2 & 64 & 68.8 & 66 & 68.8 \\
\hline \multirow{2}{*}{$\begin{array}{l}\text { Private } \\
\text { insurance }\end{array}$} & Yes & 3 & 6.8 & 13 & 15.7 & 34 & 40.5 & 46 & 49.5 & 38 & 39.6 \\
\hline & No & 41 & 93.2 & 70 & 84.3 & 50 & 59.5 & 47 & 50.5 & 58 & 60.4 \\
\hline \multirow{2}{*}{ Auto. pay. order } & Yes & 15 & 34.1 & 39 & 47.0 & 51 & 60.7 & 57 & 61.3 & 46 & 47.9 \\
\hline & No & 29 & 65.9 & 44 & 53.0 & 33 & 39.3 & 36 & 38.7 & 50 & 52.1 \\
\hline
\end{tabular}


(Table 5 continued)

\begin{tabular}{|c|c|c|c|c|c|c|c|c|c|c|c|}
\hline & & \multicolumn{10}{|c|}{ Age group } \\
\hline & & \multicolumn{2}{|c|}{$15-20$} & \multicolumn{2}{|c|}{$21-25$} & \multicolumn{2}{|c|}{$26-30$} & \multicolumn{2}{|c|}{$31-35$} & \multicolumn{2}{|c|}{$35+$} \\
\hline & & $\mathrm{F}$ & $\%$ & $\mathrm{~F}$ & $\%$ & $\mathrm{~F}$ & $\%$ & $\mathrm{~F}$ & $\%$ & $\mathrm{~F}$ & $\%$ \\
\hline \multirow{2}{*}{ VPOS } & Yes & 26 & 59.1 & 64 & 77.1 & 68 & 81.0 & 67 & 72.0 & 47 & 49.0 \\
\hline & No & 18 & 40.9 & 19 & 22.9 & 16 & 19.0 & 26 & 28.0 & 49 & 51.0 \\
\hline \multirow{2}{*}{ Investment trust } & Yes & 0 & 0.0 & 2 & 2.4 & 11 & 13.1 & 12 & 12.9 & 12 & 12.5 \\
\hline & No & 44 & 100 & 81 & 97.6 & 73 & 86.9 & 81 & 87.1 & 84 & 87.5 \\
\hline
\end{tabular}

The ATM was again the most frequently used financial innovation in all groups and investment trust was the least frequently used financial innovation in all age groups. Individuals in the 15-20 years old age group never used investment trust and individuals in the 26-30 years old age group preferred to use investment trust the most (13.1\%).

The financial innovation utilization ratios of individuals based on their educational levels are provided in Table 6.

Table 6

Financial Innovation Utilization Ratios Based on Educational Levels

\begin{tabular}{|c|c|c|c|c|c|c|c|c|c|c|c|c|c|}
\hline & & \multicolumn{12}{|c|}{ Educational level } \\
\hline & & \multicolumn{3}{|c|}{ Primary school } & $\begin{array}{l}\text { Secondary } \\
\text { School }\end{array}$ & \multicolumn{2}{|c|}{$\begin{array}{l}\text { High } \\
\text { School }\end{array}$} & \multicolumn{2}{|c|}{$\begin{array}{c}\text { Associate } \\
\text { degree }\end{array}$} & \multicolumn{2}{|c|}{ Undergraduate } & \multicolumn{2}{|c|}{ Graduate } \\
\hline & & $\mathrm{F}$ & $\%$ & $\mathrm{~F}$ & $\%$ & $\mathrm{~F}$ & $\%$ & $\mathrm{~F}$ & $\%$ & $\mathrm{~F}$ & $\%$ & $\mathrm{~F}$ & $\%$ \\
\hline \multirow{2}{*}{ ATM } & Yes & 14 & 70.0 & 45 & 91.8 & 113 & 98.3 & 58 & 98.3 & 149 & 100.0 & 8 & 100.0 \\
\hline & No & 6 & 30.0 & 4 & 8.2 & 2 & 1.7 & 1 & 1.7 & 0 & 0.0 & 0 & 0.0 \\
\hline \multirow{2}{*}{ Internet bank } & Yes & 3 & 15.0 & 8 & 16.3 & 80 & 69.6 & 42 & 71.2 & 132 & 88.6 & 8 & 100.0 \\
\hline & No & 17 & 85.0 & 41 & 83.7 & 35 & 30.4 & 17 & 28.8 & 17 & 11.4 & 0 & 0.0 \\
\hline \multirow{2}{*}{ Telephone bank } & Yes & 6 & 30.0 & 15 & 30.6 & 92 & 80.0 & 43 & 72.9 & 138 & 92.6 & 8 & 100.0 \\
\hline & No & 14 & 70.0 & 34 & 69.4 & 23 & 20.0 & 16 & 27.1 & 11 & 7.4 & 0 & 0.0 \\
\hline \multirow{2}{*}{ Mobile bank } & Yes & 3 & 15.0 & 8 & 16.3 & 80 & 69.6 & 40 & 67.8 & 133 & 89.3 & 7 & 87.5 \\
\hline & No & 17 & 85.0 & 41 & 83.7 & 35 & 30.4 & 19 & 32.2 & 16 & 10.7 & 1 & 12.5 \\
\hline \multirow{2}{*}{ EFT } & Yes & 1 & 5.0 & 9 & 18.4 & 62 & 53.9 & 32 & 54.2 & 125 & 83.9 & 7 & 87.5 \\
\hline & No & 19 & 95.0 & 40 & 81.6 & 53 & 46.1 & 27 & 45.8 & 24 & 16.1 & 1 & 12.5 \\
\hline \multirow{2}{*}{ Credit card } & Yes & 10 & 50.0 & 24 & 49.0 & 74 & 64.3 & 53 & 89.8 & 141 & 94.6 & 8 & 100.0 \\
\hline & No & 10 & 50.0 & 25 & 51.0 & 41 & 35.7 & 6 & 10.2 & 8 & 5.4 & 0 & 0.0 \\
\hline \multirow{2}{*}{ PPS } & Yes & 2 & 10.0 & 2 & 4.1 & 14 & 12.2 & 18 & 30.5 & 58 & 38.9 & 6 & 75.0 \\
\hline & No & 18 & 90.0 & 47 & 95.9 & 101 & 87.8 & 41 & 69.5 & 91 & 61.1 & 2 & 25.0 \\
\hline \multirow{2}{*}{ Mortgage loan } & Yes & 2 & 10.0 & 4 & 8.2 & 12 & 10.4 & 9 & 15.3 & 35 & 23.5 & 5 & 62.5 \\
\hline & No & 18 & 90.0 & 45 & 91.8 & 103 & 89.6 & 50 & 84.7 & 114 & 76.5 & 3 & 37.5 \\
\hline \multirow{2}{*}{ Consumer loan } & Yes & 5 & 25.0 & 9 & 18.4 & 18 & 15.7 & 13 & 22.0 & 49 & 32.9 & 6 & 75.0 \\
\hline & No & 15 & 75.0 & 40 & 81.6 & 97 & 84.3 & 46 & 78.0 & 100 & 67.1 & 2 & 25.0 \\
\hline \multirow{2}{*}{$\begin{array}{l}\text { Private } \\
\text { insurance }\end{array}$} & Yes & 2 & 10.0 & 10 & 20.4 & 21 & 18.3 & 19 & 32.2 & 78 & 52.3 & 4 & 50.0 \\
\hline & No & 18 & 90.0 & 39 & 79.6 & 94 & 81.7 & 40 & 67.8 & 71 & 47.7 & 4 & 50.0 \\
\hline \multirow{2}{*}{ Auto. pay. order } & Yes & 2 & 10.0 & 10 & 20.4 & 51 & 44.3 & 28 & 47.5 & 110 & 73.8 & 7 & 87.5 \\
\hline & No & 18 & 90.0 & 39 & 79.6 & 64 & 55.7 & 31 & 52.5 & 39 & 26.2 & 1 & 12.5 \\
\hline \multirow{2}{*}{ VPOS } & Yes & 1 & 5.0 & 18 & 36.7 & 69 & 60.0 & 48 & 81.4 & 130 & 87.2 & 6 & 75.0 \\
\hline & No & 19 & 95.0 & 31 & 63.3 & 46 & 40.0 & 11 & 18.6 & 19 & 12.8 & 2 & 25.0 \\
\hline \multirow{2}{*}{ Investment trust } & Yes & 0 & 0.0 & 0 & 0.0 & 5 & 4.3 & 0 & 0.0 & 29 & 19.5 & 3 & 37.5 \\
\hline & No & 20 & 100 & 49 & 100 & 110 & 95.7 & 59 & 100 & 120 & 80.5 & 5 & 62.5 \\
\hline
\end{tabular}


Considering the financial innovation utilization ratios of different educational levels, it was observed that the ATM was the most frequently used financial instrument and the credit card was the second most frequently used. The utilization ratios of these instruments increased with increasing educational level of the participants. Regardless of the educational level, investment trust was the least frequently used financial instrument. Investment trusts were preferred only by individuals with undergraduate $(19.5 \%)$ and graduate $(37.5 \%)$ level education.

The financial innovation utilization ratios of individuals based on their income levels are provided in Table 7.

Table 7

Financial Innovation Utilization Ratios Based on Income Levels

\begin{tabular}{|c|c|c|c|c|c|c|c|c|c|c|c|}
\hline & & \multicolumn{10}{|c|}{ Income level ( $(/$ month) } \\
\hline & & \multicolumn{2}{|c|}{ 1,000も and below } & \multicolumn{2}{|c|}{ 1,001も-2,000も } & \multicolumn{2}{|c|}{ 2,001も-3,000も } & \multicolumn{2}{|c|}{ 3,001も-4,000も } & \multicolumn{2}{|c|}{ 4,000も and over } \\
\hline & & $\bar{F}$ & $\%$ & $\mathrm{~F}$ & $\%$ & $\mathrm{~F}$ & $\%$ & $\mathrm{~F}$ & $\%$ & $\mathrm{~F}$ & $\%$ \\
\hline \multirow{2}{*}{ ATM } & Yes & 91 & 91.0 & 102 & 98.1 & 86 & 98.9 & 79 & 100.0 & 29 & 96.7 \\
\hline & No & 9 & 9.0 & 2 & 1.9 & 1 & 1.1 & 0 & 0.0 & 1 & 3.3 \\
\hline \multirow{2}{*}{ Internet bank } & Yes & 61 & 61.0 & 55 & 52.9 & 66 & 75.9 & 64 & 81.0 & 27 & 90.0 \\
\hline & No & 39 & 39.0 & 49 & 47.1 & 21 & 24.1 & 15 & 19.0 & 3 & 10.0 \\
\hline \multirow{2}{*}{$\begin{array}{l}\text { Telephone } \\
\text { bank }\end{array}$} & Yes & 64 & 64.0 & 66 & 63.5 & 74 & 85.1 & 70 & 88.6 & 28 & 93.3 \\
\hline & No & 36 & 36.0 & 38 & 36.5 & 13 & 14.9 & 9 & 11.4 & 2 & 6.7 \\
\hline \multirow{2}{*}{ Mobile bank } & Yes & 56 & 56.0 & 57 & 54.8 & 66 & 75.9 & 67 & 84.8 & 25 & 83.3 \\
\hline & No & 44 & 44.0 & 47 & 45.2 & 21 & 24.1 & 12 & 15.2 & 5 & 16.7 \\
\hline \multirow{2}{*}{ EFT } & Yes & 37 & 37.0 & 46 & 44.2 & 63 & 72.4 & 65 & 82.3 & 25 & 83.3 \\
\hline & No & 63 & 63.0 & 58 & 55.8 & 24 & 27.6 & 14 & 17.7 & 5 & 16.7 \\
\hline \multirow{2}{*}{ Credit card } & Yes & 56 & 56.0 & 74 & 71.2 & 79 & 90.8 & 73 & 92.4 & 28 & 93.3 \\
\hline & No & 44 & 44.0 & 30 & 28.8 & 8 & 9.2 & 6 & 7.6 & 2 & 6.7 \\
\hline \multirow{2}{*}{ PPS } & Yes & 3 & 3.0 & 15 & 14.4 & 28 & 32.2 & 35 & 44.3 & 19 & 63.3 \\
\hline & No & 97 & 97.0 & 89 & 85.6 & 59 & 67.8 & 44 & 55.7 & 11 & 36.7 \\
\hline \multirow{2}{*}{$\begin{array}{l}\text { Mortgage } \\
\text { loan }\end{array}$} & Yes & 4 & 4.0 & 10 & 9.6 & 17 & 19.5 & 24 & 30.4 & 12 & 40.0 \\
\hline & No & 96 & 96.0 & 94 & 90.4 & 70 & 80.5 & 55 & 69.6 & 18 & 60.0 \\
\hline \multirow{2}{*}{$\begin{array}{l}\text { Consumer } \\
\text { loan }\end{array}$} & Yes & 6 & 6.0 & 19 & 18.3 & 25 & 28.7 & 33 & 41.8 & 17 & 56.7 \\
\hline & No & 94 & 94.0 & 85 & 81.7 & 62 & 71.3 & 46 & 58.2 & 13 & 43.3 \\
\hline \multirow{2}{*}{$\begin{array}{l}\text { Private } \\
\text { insurance }\end{array}$} & Yes & 5 & 5.0 & 20 & 19.2 & 34 & 39.1 & 52 & 65.8 & 23 & 76.7 \\
\hline & No & 95 & 95.0 & 84 & 80.8 & 53 & 60.9 & 27 & 34.2 & 7 & 23.3 \\
\hline \multirow{2}{*}{$\begin{array}{l}\text { Auto. pay. } \\
\text { order }\end{array}$} & Yes & 26 & 26.0 & 46 & 44.2 & 50 & 57.5 & 64 & 81.0 & 22 & 73.3 \\
\hline & No & 74 & 74.0 & 58 & 55.8 & 37 & 42.5 & 15 & 19.0 & 8 & 26.7 \\
\hline \multirow{2}{*}{ VPOS } & Yes & 61 & 61.0 & 58 & 55.8 & 60 & 69.0 & 70 & 88.6 & 23 & 76.7 \\
\hline & No & 39 & 39.0 & 46 & 44.2 & 27 & 31.0 & 9 & 11.4 & 7 & 23.3 \\
\hline \multirow{2}{*}{$\begin{array}{l}\text { Investment } \\
\text { trust }\end{array}$} & Yes & 1 & 1.0 & 2 & 1.9 & 3 & 3.4 & 19 & 24.1 & 12 & 40.0 \\
\hline & No & 99 & 99.0 & 102 & 98.1 & 84 & 96.6 & 60 & 75.9 & 18 & 60.0 \\
\hline
\end{tabular}

Although investment trusts were never used by some demographic groups, it was observed that they were used by all income groups of the research sample.

The financial innovation utilization ratios of individuals based on their occupations are provided in Table 8 .

The Pearson Chi-Square analysis was performed with SPSS 22.0 software to test the significance of differences in the financial innovation utilization ratios of the "Successful" and "Unsuccessful" financial literacy groups. Analysis results are provided in Table 9. 
Table 8

Financial Innovation Utilization Ratios of Occupation Groups

\begin{tabular}{|c|c|c|c|c|c|c|c|c|c|c|c|c|c|c|c|c|c|c|c|}
\hline & & \multicolumn{18}{|c|}{ Occupation } \\
\hline & & \multicolumn{2}{|c|}{ Unemployed } & \multicolumn{2}{|c|}{$\begin{array}{c}\text { Private sector } \\
\text { (blue-collar) }\end{array}$} & \multicolumn{2}{|c|}{$\begin{array}{l}\text { Private sector } \\
\text { (white-collar) }\end{array}$} & \multicolumn{2}{|c|}{$\begin{array}{l}\text { Public sector } \\
\text { (blue-collar) }\end{array}$} & \multicolumn{2}{|c|}{$\begin{array}{l}\text { Public sector } \\
\text { (white-collar) }\end{array}$} & \multicolumn{2}{|c|}{ Self-employed } & \multicolumn{2}{|r|}{ Retired } & \multicolumn{2}{|c|}{ Housewife } & \multicolumn{2}{|c|}{ Student } \\
\hline & & $\mathrm{F}$ & $\%$ & $\mathrm{~F}$ & $\%$ & $\mathrm{~F}$ & $\%$ & $\mathrm{~F}$ & $\%$ & $\mathrm{~F}$ & $\%$ & $\mathrm{~F}$ & $\%$ & $\mathrm{~F}$ & $\%$ & $\mathrm{~F}$ & $\%$ & $\mathrm{~F}$ & $\%$ \\
\hline \multirow{2}{*}{ ATM } & Yes & 21 & 100.0 & 103 & 100.0 & 59 & 100.0 & 31 & 100.0 & 48 & 100.0 & 48 & 96.0 & 13 & 92.9 & 8 & 57.1 & 56 & 93.3 \\
\hline & No & 0 & 0.0 & 0 & 0.0 & 0 & 0.0 & 0 & 0.0 & 0 & 0.0 & 2 & 4.0 & 1 & 7.1 & 6 & 42.9 & 4 & 6.7 \\
\hline \multirow{2}{*}{$\begin{array}{l}\text { Internet } \\
\text { bank }\end{array}$} & Yes & 18 & 85.7 & 60 & 58.3 & 48 & 81.4 & 25 & 80.6 & 43 & 89.6 & 34 & 68.0 & 3 & 21.4 & 0 & 0.0 & 42 & 70.0 \\
\hline & No & 3 & 14.3 & 43 & 41.7 & 11 & 18.6 & 6 & 19.4 & 5 & 10.4 & 16 & 32.0 & 11 & 78.6 & 14 & 100.0 & 18 & 30.0 \\
\hline \multirow{2}{*}{$\begin{array}{l}\text { Telephone } \\
\text { bank }\end{array}$} & Yes & 19 & 90.5 & 70 & 68.0 & 50 & 84.7 & 27 & 87.1 & 44 & 91.7 & 41 & 82.0 & 6 & 42.9 & 3 & 21.4 & 42 & 70.0 \\
\hline & No & 2 & 9.5 & 33 & 32.0 & 9 & 15.3 & 4 & 12.9 & 4 & 8.3 & 9 & 18.0 & 8 & 57.1 & 11 & 78.6 & 18 & 30.0 \\
\hline \multirow{2}{*}{ Mobile bank } & Yes & 17 & 81.0 & 63 & 61.2 & 48 & 81.4 & 25 & 80.6 & 39 & 81.3 & 37 & 74.0 & 4 & 28.6 & 0 & 0.0 & 38 & 63.3 \\
\hline & No & 4 & 19.0 & 40 & 38.8 & 11 & 18.6 & 6 & 19.4 & 9 & 18.8 & 13 & 26.0 & 10 & 71.4 & 14 & 100 & 22 & 36.7 \\
\hline \multirow{2}{*}{ EFT } & Yes & 12 & 57.1 & 45 & 43.7 & 48 & 81.4 & 21 & 67.7 & 41 & 85.4 & 38 & 76.0 & 2 & 14.3 & 0 & 0.0 & 29 & 48.3 \\
\hline & No & 9 & 42.9 & 58 & 56.3 & 11 & 18.6 & 10 & 32.3 & 7 & 14.6 & 12 & 24.0 & 12 & 85.7 & 14 & 100.0 & 31 & 51.7 \\
\hline \multirow{2}{*}{ Credit card } & Yes & 16 & 76.2 & 77 & 74.8 & 57 & 96.6 & 27 & 87.1 & 44 & 91.7 & 43 & 86.0 & 9 & 64.3 & 4 & 28.6 & 33 & 55.0 \\
\hline & No & 5 & 23.8 & 26 & 25.2 & 2 & 3.4 & 4 & 12.9 & 4 & 8.3 & 7 & 14.0 & 5 & 35.7 & 10 & 71.4 & 27 & 45.0 \\
\hline \multirow{2}{*}{ PPS } & Yes & 2 & 9.5 & 18 & 17.5 & 23 & 39.0 & 11 & 35.5 & 23 & 47.9 & 20 & 40.0 & 1 & 7.1 & 0 & 0.0 & 2 & 3.3 \\
\hline & No & 19 & 90.5 & 85 & 82.5 & 36 & 61.0 & 20 & 64.5 & 25 & 52.1 & 30 & 60.0 & 13 & 92.9 & 14 & 100 & 58 & 96.7 \\
\hline \multirow{2}{*}{$\begin{array}{l}\text { Mortgage } \\
\text { loan }\end{array}$} & Yes & 2 & 9.5 & 15 & 14.6 & 12 & 20.3 & 6 & 19.4 & 13 & 27.1 & 15 & 30.0 & 3 & 21.4 & 1 & 7.1 & 0 & 0.0 \\
\hline & No & 19 & 90.5 & 88 & 85.4 & 47 & 79.7 & 25 & 80.6 & 35 & 72.9 & 35 & 70.0 & 11 & 78.6 & 13 & 92.9 & 60 & 100.0 \\
\hline \multirow{2}{*}{$\begin{array}{l}\text { Consumer } \\
\text { Loan }\end{array}$} & Yes & 1 & 4.8 & 26 & 25.2 & 12 & 20.3 & 11 & 35.5 & 17 & 35.4 & 21 & 42.0 & 7 & 50.0 & 2 & 14.3 & 3 & 5.0 \\
\hline & No & 20 & 95.2 & 77 & 74.8 & 47 & 79.7 & 20 & 64.5 & 31 & 64.6 & 29 & 58.0 & 7 & 50.0 & 12 & 85.7 & 57 & 95.0 \\
\hline \multirow{2}{*}{$\begin{array}{l}\text { Private } \\
\text { insurance }\end{array}$} & Yes & 2 & 9.5 & 25 & 24.3 & 23 & 39.0 & 17 & 54.8 & 26 & 54.2 & 34 & 68.0 & 3 & 21.4 & 1 & 7.1 & 3 & 5.0 \\
\hline & No & 19 & 90.5 & 78 & 75.7 & 36 & 61.0 & 14 & 45.2 & 22 & 45.8 & 16 & 32.0 & 11 & 78.6 & 13 & 92.9 & 57 & 95.0 \\
\hline \multirow{2}{*}{$\begin{array}{l}\text { Auto. pay. } \\
\text { order }\end{array}$} & Yes & 9 & 42.9 & 45 & 43.7 & 40 & 67.8 & 20 & 64.5 & 35 & 72.9 & 34 & 68.0 & 8 & 57.1 & 0 & 0.0 & 17 & 28.3 \\
\hline & No & 12 & 57.1 & 58 & 56.3 & 19 & 32.2 & 11 & 35.5 & 13 & 27.1 & 16 & 32.0 & 6 & 42.9 & 14 & 100 & 43 & 71.7 \\
\hline \multirow{2}{*}{ VPOS } & Yes & 17 & 81.0 & 60 & 58.3 & 52 & 88.1 & 24 & 77.4 & 39 & 81.3 & 37 & 74.0 & 3 & 21.4 & 2 & 14.3 & 38 & 63.3 \\
\hline & No & 4 & 19.0 & 43 & 41.7 & 7 & 11.9 & 7 & 22.6 & 9 & 18.8 & 13 & 26.0 & 11 & 78.6 & 12 & 85.7 & 22 & 36.7 \\
\hline \multirow{2}{*}{$\begin{array}{l}\text { Investment } \\
\text { trust }\end{array}$} & Yes & 0 & 0.0 & 2 & 1.9 & 11 & 18.6 & 5 & 16.1 & 5 & 10.4 & 12 & 24.0 & 1 & 7.1 & 0 & 0.0 & 1 & 1.7 \\
\hline & No & 21 & 100.0 & 101 & 98.1 & 48 & 81.4 & 26 & 83.9 & 43 & 89.6 & 38 & 76.0 & 13 & 92.9 & 14 & 100.0 & 59 & 98.3 \\
\hline
\end{tabular}


Table 9:

Test Results for the Relationships Between Financial Literacy Levels and Financial Innovation Utilization Habits

\begin{tabular}{|c|c|c|c|c|c|c|c|c|c|c|c|c|c|c|c|}
\hline & & & \multicolumn{13}{|c|}{ Financial Innovations } \\
\hline & & & ATM & $\begin{array}{l}\text { Internet } \\
\text { bank }\end{array}$ & $\begin{array}{l}\text { Telephone } \\
\text { bank }\end{array}$ & $\begin{array}{l}\text { Mobile } \\
\text { bank }\end{array}$ & EFT & $\begin{array}{l}\text { Credit } \\
\text { card }\end{array}$ & PPS & $\begin{array}{l}\text { Mortgage } \\
\text { loan }\end{array}$ & $\begin{array}{l}\text { Consumer } \\
\text { loan }\end{array}$ & $\begin{array}{l}\text { Private } \\
\text { insurance }\end{array}$ & $\begin{array}{l}\text { Auto. pay. } \\
\text { order }\end{array}$ & VPOS & $\begin{array}{l}\text { Investment } \\
\text { trust }\end{array}$ \\
\hline \multirow{8}{*}{ 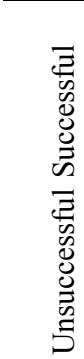 } & \multirow{2}{*}{ Yes } & $\mathrm{F}$ & 321 & 230 & 256 & 227 & 201 & 260 & 89 & 54 & 81 & 121 & 178 & 233 & 37 \\
\hline & & $\%$ & 98.80 & 70.80 & 78.80 & 69.80 & 61.80 & 80.00 & 27.40 & 16.60 & 24.90 & 37.20 & 54.80 & 71.70 & 11.40 \\
\hline & \multirow{2}{*}{ No } & $\mathrm{F}$ & 4 & 95 & 69 & 98 & 124 & 65 & 236 & 271 & 244 & 204 & 147 & 92 & 288 \\
\hline & & $\%$ & 1.20 & 29.20 & 21.20 & 30.20 & 38.20 & 20.00 & 72.60 & 83.40 & 75.10 & 62.80 & 45.20 & 28.30 & 88.60 \\
\hline & \multirow{2}{*}{ Yes } & $\mathrm{F}$ & 66 & 43 & 46 & 44 & 35 & 50 & 11 & 13 & 19 & 13 & 30 & 39 & 0 \\
\hline & & $\%$ & 88.00 & 57.30 & 61.30 & 50.80 & 44.30 & 66.70 & 14.70 & 17.30 & 25.30 & 17.30 & 40.00 & 52.00 & 0.00 \\
\hline & \multirow{3}{*}{ No } & $\mathrm{F}$ & 9 & 32 & 29 & 31 & 40 & 25 & 64 & 62 & 56 & 62 & 45 & 36 & 75 \\
\hline & & $\%$ & 12.00 & 42.70 & 38.70 & 24.20 & 30.80 & 16.90 & 85.30 & 82.70 & 74.70 & 82.70 & 60.00 & 48.00 & 100.00 \\
\hline Total & & & 400 & 400 & 400 & 400 & 400 & 400 & 400 & 400 & 400 & 400 & 400 & 400 & 400 \\
\hline$\chi^{2}$ & & & 22.476 & 5.077 & 10.015 & 3.486 & 5.804 & 6.213 & 5.257 & 0.023 & 0.005 & 10.830 & 5.325 & 10.860 & 9.409 \\
\hline$p$ & & & $0.000^{*}$ & $0.024 *$ & $0.002 *$ & $0.062 * *$ & $0.016^{*}$ & $0.013^{*}$ & $0.022^{*}$ & 0.881 & 0.941 & $0.001^{*}$ & $0.021 *$ & $0.001 *$ & $0.002 *$ \\
\hline$\phi$ & & & 0.237 & 0.113 & 0.158 & 0.093 & 0.120 & 0.125 & 0.115 & -0.008 & -0.004 & 0.165 & 0.115 & 0.165 & 0.153 \\
\hline
\end{tabular}

Notes. * significant at 0.05 significance level; ** significant at 0.10 significance level. 
Considering the resultant $p$ values, the $\mathrm{H}_{0}$ hypothesis was accepted for "Mortgage Loan" and "Personal Loan". In other words, significant differences were not observed in the utilization habits of these two financial innovations between the "Successful" and "Unsuccessful" groups. For "Mobile Banking", the $\mathrm{H}_{0}$ hypothesis was rejected at a $10 \%$ significance level, but the $\mathrm{H}_{1}$ hypothesis was accepted. For the other financial innovations, the $\mathrm{H}_{0}$ hypothesis was rejected at a 5\% significance level and the $\mathrm{H}_{1}$ hypothesis was accepted. In other words, for relevant financial innovations, the relationships between financial literacy success status and financial innovation utilization habits were not found to be significant.

\section{Conclusion}

In this study, an answer was searched to the question "Are there any significant relationships between the financial literacy levels of individuals and their financial innovation utilization habits?" For this purpose, a questionnaire composed of three main sections was prepared. The first section of the questionnaire inquired into the demographic characteristics of individuals, the second section inquired into their financial literacy levels, and the last section inquired into their financial innovation utilization habits. Individuals living in Kayseri province constituted the research universe. Then, a research sample was created so as to represent this universe qualitatively and quantitatively and questionnaires were applied to this sample.

In the second section inquiring into the financial literacy levels of individuals, the guidelines set by the OECD to measure financial literacy levels and recent studies on financial literacy were used. Along with the OECD guidelines, participants were asked questions about "simple division", "time value of Money", "paid interest", "simple interest", "compound interest", "risk and return", "inflation", and "financial diversification". Individuals with four and less correct answers to eight questions were placed in the "Unsuccessful" group and those with five and more correct answers were placed in "Successful" group. Of the participating individuals, $18.8 \%$ were placed in the "Unsuccessful" group and $81.2 \%$ were placed in the "Successful" group.

Considering the financial innovation utilization habits of the "Unsuccessful" and "Successful" groups in general, it was observed that there were no individuals in the "Unsuccessful" group who did not use any of the financial innovations. In other words, even individuals who were placed in the "Unsuccessful" group with regard to financial literacy preferred to use at least one financial innovation. In the "Successful" group, the ratio of individuals not using any of the financial innovations was $1.23 \%$. Of the "Unsuccessful" with regard to financial literacy on the other hand, $9.3 \%$ used all of the financial innovations. However, none of the individuals in the "Successful" group used all of the financial innovations. Considering the most frequently used innovations of the groups, it was observed that $16.9 \%$ of the "Successful" group used five of the financial innovations and $16.0 \%$ of the "Unsuccessful" group used seven of the financial innovations.

The effects of financial the literacy success status of individuals living in Kayseri province on their financial innovation utilization habits were also investigated in this study. There were no significant differences in "Mortgage Loan" and "Consumer Loan" utilization habits between financial literacy success statuses. However, for the other financial innovations, there were significant relationships between utilization habits and the financial literacy success status of individuals.

\section{References}

Aksoylu, S., Boztosun, D., Altinişik, F., \& Baraz, E. H. (2017). A baseline investigation of financial literacy levels: The case of Kayseri province. Muhasebe ve Finansman Dergisi, 75, 229-245. 
Alkaya, A., \& Yağlı, İ. (2015). Finansal okuryazarlık-finansal bilgi, davranış ve tutum: Nevşehir Hacı Bektaş Veli Üniversitesi İİBF öğrencileri üzerine bir uygulama. Journal of International Social Research, 8(40), 585-599.

Atkinson, A., \& Messy, F. A. (2012). Measuring financial literacy: Results of the OECD INFE pilot study (Finansal Okuryazarlığın Ölçümü: OECD INFE Pilot Çalışması Sonuçları). OECD Working Papers on Finance, Insurance and Private Pensions, No. 15, OECD Publishing.

Bhushan, P. (2014). Insights into awareness level and investment behaviour of salaried individuals towards financial products. International Journal of Engineering, Business and Enterprise Applications, 8(1), 53-57.

Bodie, Z. (2006). A note on economic principles and financial literacy, Networks Financial Institute at Indiana State University Policy Brief.

Cihangir, M., \& Ergin, E. (2015). Finansal okuryazarlığın temel düzeyde incelenmesi: Osmaniye ilinde ankete dayalı bir araştırma. Akadaemik Sosyal Araştırmalar Dergisi, 3(13), 492-511.

Crain, S. (2013). Are universities improving students financial literacy? A study of general education curriculum. Journal of Financial Education, Spring/Summer, 1-18.

Çıkrıkçı, M., \& Karakaya, A. (2004). Finansal ürünlerin kullanımı ve memnuniyeti: Türkiye'deki banka müşterileri üzerine bir çalışma. Bankacılar Dergisi, 51, 37-49.

Delaune, L. D., Rakow, J. S., \& Rakow, K. C. (2010). Teaching financial literacy in a co-curricular service-learning model. Journal of Accounting Education, (28), April, 103-113.

Fettahoğlu, S. (2015). Hane Halkının Finans Eğitimi ve Finansal Okuryazarlık Düzeyleri Üzerine Kocaeli'nde Bir Araştırma. Muhasebe ve Finansman Dergisi, (67), 101-115.

Fluch, M. (2007). Selected central banks' economic and financial literacy programs. Monetary Policy \& the Economy, Q3/07, 85-104.

Frame, W. S., \& White, L. J. (2002). Empirical studies of financial innovation: Lots of talk, little action? FRB of Atlanta Working Paper No: 2002-12.

Goel, I., \& Khanna, S. R. (2013). Financial education as tool to achieve financial literacy. Eastern Economic Forum, 338-345.

Hastings, J. S., Madrian, B. C., \& Skimmyhom, W. L. (2012). Financial literacy, financial education and economic outcomes. Annual Review of Economics, (5), 347-373.

Hilgert, M., \& Hogarth, J. M. (July, 2003). Household financial management: The connection between knowledge and behavior. Federal Reserve Bulletin, 309-322.

Llewellyn, D. T. (1992). Financial innovation: A basic analysis. In H. Cavana (Ed.), Financial innovation (pp. 14-51). London.

Lusardi, A., \& Tufano, P. (2009). Debt literacy, financial experiences, and overindebtedness. National Bureau of Economic Research Working Paper, No: 14808.

Lusardi, A. (2008). Financial literacy: An essential tool for informed consumer choice? National Bureau of Economic Research Paper, No: 14084.

Minehan, C. E. (2006). The role of central banks in economic and personal finance education. International Conference of Central Bankers and Economic Educators (28-29.11.2006), Warsaw: Poland.

Podolski, T. M. (1986). Financial innovation and money supply. Oxford: Basil Blackwell.

Remund, L. D. (2010). Financial literacy explicated: The case for a clearer definition in an increasingly complex economy. The Journal of Consumer Affairs, 44(2), 276-295.

Tufano, P. (2002). Financial innovation (Chapter 6 in Handbook of the Economics of Finance, Edited by George M. Constantinides, Milton Harris and Rene M. Stulz in 2003).

Van Horne, J. C. (1985). Of financial innovation and excesses. The Journal of Finance, 40(3), 620-631.

Wakelin, K. (1998). Innovation and export behaviour at the firm level. Research Policy, 26(7), 829-841.

Wimmer, R. D., \& Dominick, J. R. (2000). Mass media research: An introduction. Belmont, CA: Wadsworth Publishing.

Worthington, A. (2006). Predicting financial literacy in Australia. Financial Services Review, 15(1), 59-79.

Yildiz, N., \& Bircan, H. (2006). Uygulamalı İstatistik (2 Bask1). Ankara: Nobel Yayın Dağıtım. 